Volume I Nomor 1 Tahun 2019

e-ISSN:

\title{
PENERAPAN METODE BERMAIN JARI TANGAN DALAM MENGEMBANGKAN KEMAMPUAN KOGNITIF PADA ANAK KELAS A DI RAUDHATUL ATHFAL MA'ARIF O1 METRO
}

\author{
Leli Fertiliana Dea ${ }^{1}$, Agus Setiawan ${ }^{2}$ \\ 1,2 Institut Agama Islam Ma'arif NU (IAIM-NU) Metro Lampung \\ ${ }^{1}$ Leli.f.dea@gmail.com, 24905as@gmail.com
}

Diterima: 21 Mei 2019 I Direvisi: 27 Mei 2019 I Disetujui: 28 Mei 2019 (C) 2019

Pendidikan Guru Raudhatul Atfhal Fakultas Agama Islam Universitas Islam Malang

\begin{abstract}
This study aims to determine whether the application of the method of finger play can develop cognitive abilities in class A children in Raudhatul Athfal Ma'arif 01 Metro. This study used a qualitative approach, with the type of Classroom Action Research (CAR). This study uses a design according to the Kemmis model and Taggart MC which consists of four stages, namely: 1. Planning, 2. Action, 3. Observation, and 4. Reflection ". The subjects of this study were class A children in Raudhatul Athfal Ma'arif 01 Metro 2018/2019 academic year as many as 15 children. The research instrument uses the method of documentation, observation and interviews. Data analysis techniques used quantitative descriptive statistics. The results of the first cycle, indicators of success in cognitive abilities are 60\% increased to $80 \%$ in cycle II.
\end{abstract}

Keyword: cognitive abilities, methods of playing fingers, early childhood.

\section{A. Pendahuluan}

Pengembangan pondasi dasar anak dapat dikembangkan melalui pendidikan taman kanak-kanak. Perkembangan fisik-motorik, intelektual, emosional, maupun spiritual dipengaruhi pendidikan prasekolah (Setiawan, 2018). Kesiapan anak untuk melangkah menuju pendidikan selanjutnya sangat dipengaruhi oleh pengembangan potensi anak ketika anak belajar di pendidikan taman kanak-kanak (Fakhruddin, 2010).

Pemerolehan perkembangan pada usia dini berpengaruh pada perkembangan anak pada fase selanjutnya dan tingkat produktivitas kerja di masa dewasa. Dari beberapa aspek perkembangan di atas, peneliti berminat untuk meneliti tentang perkembangan kognitif pada anak. Adapun yang dimaksud dengan aspek kognitif menurut Piaget adalah "aspek intelek yang dipergunakan untuk mengetahui aspek persepsi, ingatan, pikiran, simbol, penalaran dan

This work is licensed under Creative Commons Attribution Non Commercial 4.0 International License Available online on: http://riset.unisma.ac.id/index.php/fai/index 
pemecahan persoalan. Inteligensi merupakan kemampuan untuk berpikir abstrak dan menyelesaikan masalah secara efektif" (Musbikin, 2010).

Ada beberapa indikator perkembangan kognitif pada anak usia dini dalam yang sebaiknya dicapai pada pembelajaran anak usia dini, yaitu sebagaimana tabel di bawah ini:

Tabel 1. Indikator Perkembangan Kemampuan Kognitif pada Anak Usia 4-5 Tahun

\begin{tabular}{|c|l|l|}
\hline Aspek Perkembangan Kognitif & \multicolumn{1}{|c|}{ Tingkat Pencapaian Perkembangan } \\
\hline Konsep bilangan dan lambang & 1. & Mengetahui konsep banyak dan sedikit. \\
bilangan & 2. & Menyebutkan banyak benda satu sampai \\
& \multicolumn{2}{l}{ sepuluh. } \\
& 3. & Mengenal konsep bilangan. \\
& 4. & Mengenal lambang bilangan. \\
\hline
\end{tabular}

Kemendiknas (2009)

Dari beberapa aspek perkembangan kognitif di atas, peneliti mencoba untuk membatasi penelitian ini pada aspek konsep bilangan dan lambang bilangannya saja. Hal ini dilakukan karena terlalu luasnya perkembangan kognitif anak dan agar lebih terarahnya kegiatan penelitian ini sehingga dapat memberikan adanya perkembangan kemampuan kognitif dalam kegiatan belajar mengajar anak.

Dengan demikian, maka Bruner menyatakan bahwa setiap materi dapat diajarkan kepada setiap kelompok umur dengan cara-cara yang sesuai dengan perkembanganya (Musbikin, 2010). Pada materi berhitung terdapat angka di dalamnya adapun ayat Al-Qur'an yang berkaitan dengan angka terdapat dalam surah Al - A'Araaf Ayat 54 Artinya: "Sesungguhnya Tuhan kamu adalah Allah yang telah menciptakan langit dan bumi dalam enam masa. Lalu Dia bersemayam diatas 'arasy. Dia menutupkan malam kepada siang yang mengikutinya dengan cepat dan (diciptakanNya pula) matahari, bulan dan bintang-bintang (masing-masing) tunduk kepada perintahNya. Ingatlah, menciptakan dan memerintahkan hanya hak Allah. Maha suci Allah, Tuhan Semesta Alam." (Q.S. Al-A'raf: 54).

Pada surat Al-'Araaf yang berkaitan dengan angka terdapat kata Syittati yang artinya adalah enam, kata enam di sini melambangkan angka 6. Oleh karena itu ketika mengenalkan angka kepada anak hendaknya dikenalkan secara menarik sesuai dengan karakter dan perkembangan anak yaitu bermain sambil belajar atau belajar seraya bermain sesuai dengan karakter anak usia 0-6 tahun. Menurut Harjanto (2011), pada usia 4 tahun anak sudah bisa menghitung biasanya ia menghitung sampai lima atau sepuluh. Sedangkan pada usia 5 tahun, anak sudah dikenalkan bentuk-bentuk geometri, pengenalan angka belasan, dan puluhan, termasuk juga pengenalan operasi matematika, seperti penjumlahan dan 
pengurangan. Dengan dikenalkannya angka kepada anak sejak dini maka mereka akan berlatih melalui pengetahuannya dengan wujud, tolok ukur, ruang, serta simbol-simbol angka, karena dengan belajar sejak dini maka kemampuan matematis akan berkembang secara optimal.

Menurut Wahyudi (2005) "perkembangan kemampuan matematis dimulai dari masa kecilnya, dan berkelanjutan saat anak berkembang secara mental, fisik, dan sosial, yang berpengaruh secara langsung terhadap perkembangan konsep dan kemampuan mereka". Kemampuan anak untuk mengenal angka dapat dilakukan dengan berbagai cara yang mudah dipahami oleh anak yaitu melalui pengalaman belajar yang terstruktur, aktivitas pembelajaran yang terencana, dimana pendidik menemukan hal yang cukup berarti untuk diajarkan kepada anak yaitu dengan cara melalui kegiatan sehari-hari, dengan cara mengenalkan lagu yang berhubungan dengan angka, melalui kartu angka, poster angka, menunjuk jari sebagai simbol angka serta lain sebagainya (Harjanto, 2011).

Sesuai dengan beberapa cara yang diungkapkan pada teori di atas, maka penulis memandang perlu untuk mencoba penerapan sebuah metode bermain jari dalam mengembangkan kemampuan kognitif pada anak usia dini. Menurut Setyaki (2008), yang dimaksud dengan metode bermain jari atau yang biasa dikenal dengan jaritmatika ialah "suatu cara mengenalkan simbol angka 1 sampai 9 dengan memakai komposisi jari-jari tangan kanan, sehingga nilai tempat satuan untuk tangan kanan dan nilai tempat puluhan untuk tangan kiri". Sedangkan menurut Rahayu (2010), metode bermain jari yaitu "penggunaan tangan yang terdiri dari 10 jari dapat digunakan berhitung dari jumlah jarinya." Gambar simbol jari posisi satuan 1 sampai 9 ditunjukkan dengan tangan kanan.
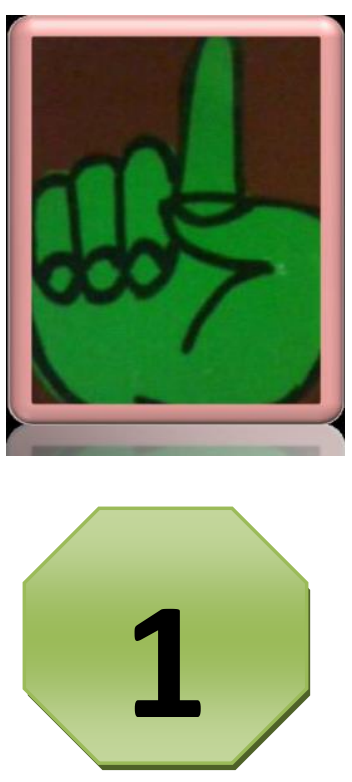
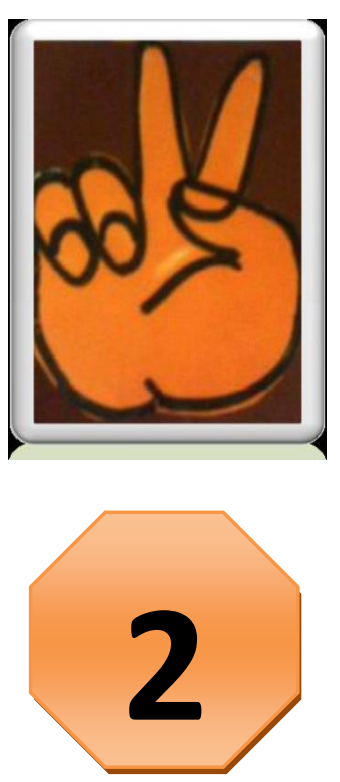
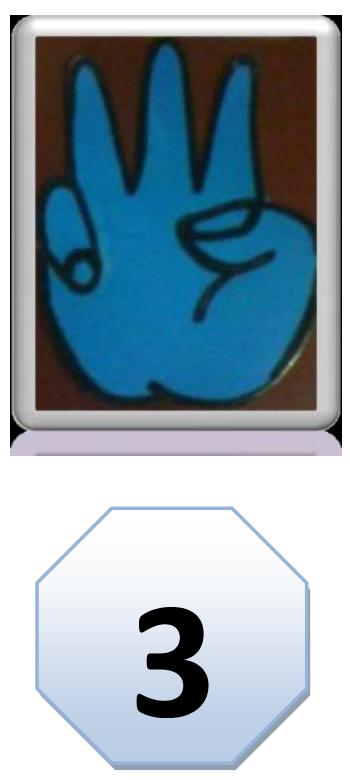

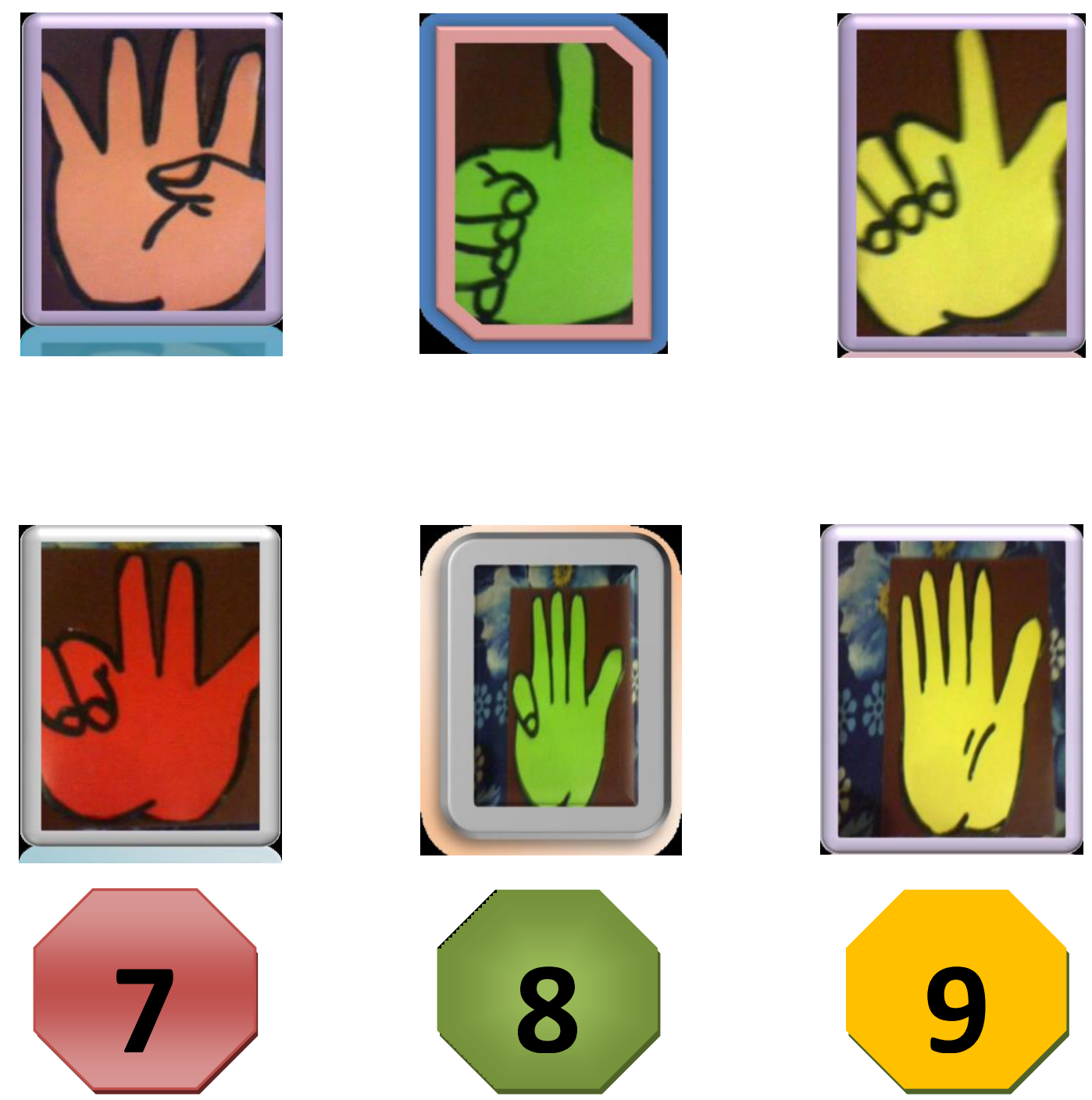

Gambar simbol jari nilai 10 puluhan ditunjukkan tangan sebelah kiri yaitu sebagai berikut.

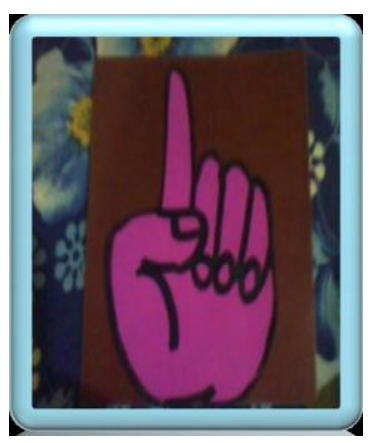


Menurut pendapat di atas, dapat disimpulkan bahwa mengenalkan angka maupun berhitung dari satuan hingga puluhan dapat dilakukan dengan memakai jari tangan kanan dan kiri. Oleh karena itu jika anak sudah siap untuk melanjutkan sekolah dasar maka mereka akan mempunyai bekal ilmu pengetahuan tentang mengenal angka serta berhitung dengan memakai kedua tangan kanan dan kirinya dengan mudah. Sesuai dengan hasil pengamatan awal, dari 15 anak yang ada hanya 6 anak atau hanya 40\% anak saja yang sudah dapat mengurutkan dan memahami urutan angka secara benar. Beberapa permasalahan yang terdapat dalam pembelajaran mengenal angka dalam penelitian ini anak belum dapat mengenal angka secara urut, anak masih bingung membedakan antara angka 6 dan 9, sehingga kemampuan mengenal angka di Raudhatul Athfal Ma'arif 01 Metroperlu ditingkatkan. Selain itu pembelajaran mengenal angka di Raudhatul Athfal Ma'arif 01 Metro tersebut tidak memakai contoh yang konkret dan anak tidak diberi pengalaman secara langsung sehingga anak pasif dan mudah bosan. Untuk lebih jelasnya, berikut penulis sajikan hasil pengamatan awal mengenai kemampuan anak dalam mengenal angka, sebagai berikut.

Tabel 2. Hasil Pengamatan Awal Kemampuan Kognitif Anak Kelas A di Raudhatul Athfal Ma'arif 01 Metro Tahun Ajaran 2018/2019

\begin{tabular}{|c|c|c|c|c|c|c|}
\hline \multirow{2}{*}{ No } & \multirow{2}{*}{ Nama Anak } & \multicolumn{4}{|c|}{ Aspek yang Diamati } & \multirow{2}{*}{ Ket. } \\
\hline & & 1 & 2 & 3 & 4 & \\
\hline 1 & Ahmad Bayhagi & BSB & MB & BSB & BSB & Berkembang Sangat Baik \\
\hline 2 & Asyila Naila Alifah & MB & MB & MB & BB & Mulai Berkembang \\
\hline 3 & Chika Meilini Putri & MB & BSB & MB & BB & Mulai Berkembang \\
\hline 4 & Clarita Putri Harsoni & $\mathrm{BB}$ & $\mathrm{MB}$ & $\mathrm{BB}$ & BB & Belum Berkembang \\
\hline 5 & Depi Rahmawati & $\mathrm{BB}$ & MB & BB & BB & Belum Berkembang \\
\hline 6 & Fariha Madinatul M & MB & $\mathrm{BB}$ & $\mathrm{BB}$ & BB & Belum Berkembang \\
\hline 7 & Filla Pratama & BSB & BSB & MB & BSB & Berkembang Sangat Baik \\
\hline 8 & Illiyin Iwankgoro & MB & BB & $\mathrm{BB}$ & BB & Belum Berkembang \\
\hline 9 & J. Mutia Az-Zahra & MB & MB & $\mathrm{MB}$ & BB & Mulai Berkembang \\
\hline 10 & Kaila Tabina & BSB & BSB & MB & BSB & Berkembang Sangat Baik \\
\hline 11 & M.Al Fairo Bintang & BSB & BSB & BSB & BSB & Berkembang Sangat Baik \\
\hline 12 & M.Raadhi Adrian & BSB & BSB & BSB & BSB & Berkembang Sangat Baik \\
\hline 13 & M.Satria Herlino & BB & MB & BB & BB & Belum Berkembang \\
\hline 14 & Mega Rohani & MB & BB & BB & BB & Belum Berkembang \\
\hline 15 & Muhammad Febrian & BSB & BSB & BSB & BSB & Berkembang Sangat Baik \\
\hline
\end{tabular}

Sumber: Pengamatan di Raudhatul Athfal Ma'arif 01 MetroTanggal 03 Februari 2019. 
Keterangan:

1. Memahami konsep banyak dan sedikit

2. Menyebutkan nama benda satu sampai sepuluh

3. Mengenal konsep bilangan

4. Mengenal lambang bilangan

BB : Belum Berkembang

MB : Mulai Berkembang

BSB : Berkemban Sangat Baik

Sesuai dengan data tabel di atas dapat diketahui bahwa kemampuan kognitif anak dalam mengenal angka masih sangat kurang. Terbukti dari 15 anak yang berkembang sangat baik hanya 6 anak atau 45\% dan yang mulai berkembang ada 3 anak atau $20 \%$ anak dan yang belum berkembang ada 5 anak atau 35\% . Oleh karena itu melalui metode bermain jari tangan yang disesuaikan dengan karakter anak usia dini yaitu dengan cara bermain sambil belajar atau belajar seraya bermain, maka diharapkan kemampuan kognitif anak dalam pengenalan angka pada anak kelas A di Raudhatul Athfal Ma'arif 01 Metro dapat ditingkatkan.

\section{B. Metode}

Penelitian ini memakai pendekatan kualitatif. Jenis penilitian ini adalah Penelitian Tindakan Kelas (PTK) yaitu suatu pembahasan yang mencerminkan pelaku tindakan melalui upaya mengembangkan kemampuan kognitif pada anak melalui metode bermain jari di Raudhatul Athfal Ma'arif 01 Metro.

Partisipasi adalah sifat penelitian ini. Penelitian ini membutuhkan keteribatan peneliti. Penelitian ini juga bersifat kerjasama karena melibatkan orang lain (guru pendidik) dalam penelitiannya (Arikunto, 2009). Adapun rencana penelitian ini memakai dua siklus, dengan asumsi sudah tercapai target dalam meningkatkan kemampuan anak mengenal angka. Begitu juga sebaliknya, apabila target belum tercapai, maka penelitian dilanjutkan pada siklus berikutnya.

\section{Desain Penelitian}

Adapun desain Penelitian Tindakan Kelas dalam penelitian ini mengacu pada model Kemmis dan MC Taggart, terdiri dari empat tahap, yaitu: 1. Perencanaan atau planning, 2. Tindakan atau acting, 3. Pengamatan atau observing, dan 4. Refleksi atau reflecting" (Arikunto, 2009). Kemmis menggambarkan tahap-tahap tersebut dalam siklus sebagai berikut. 


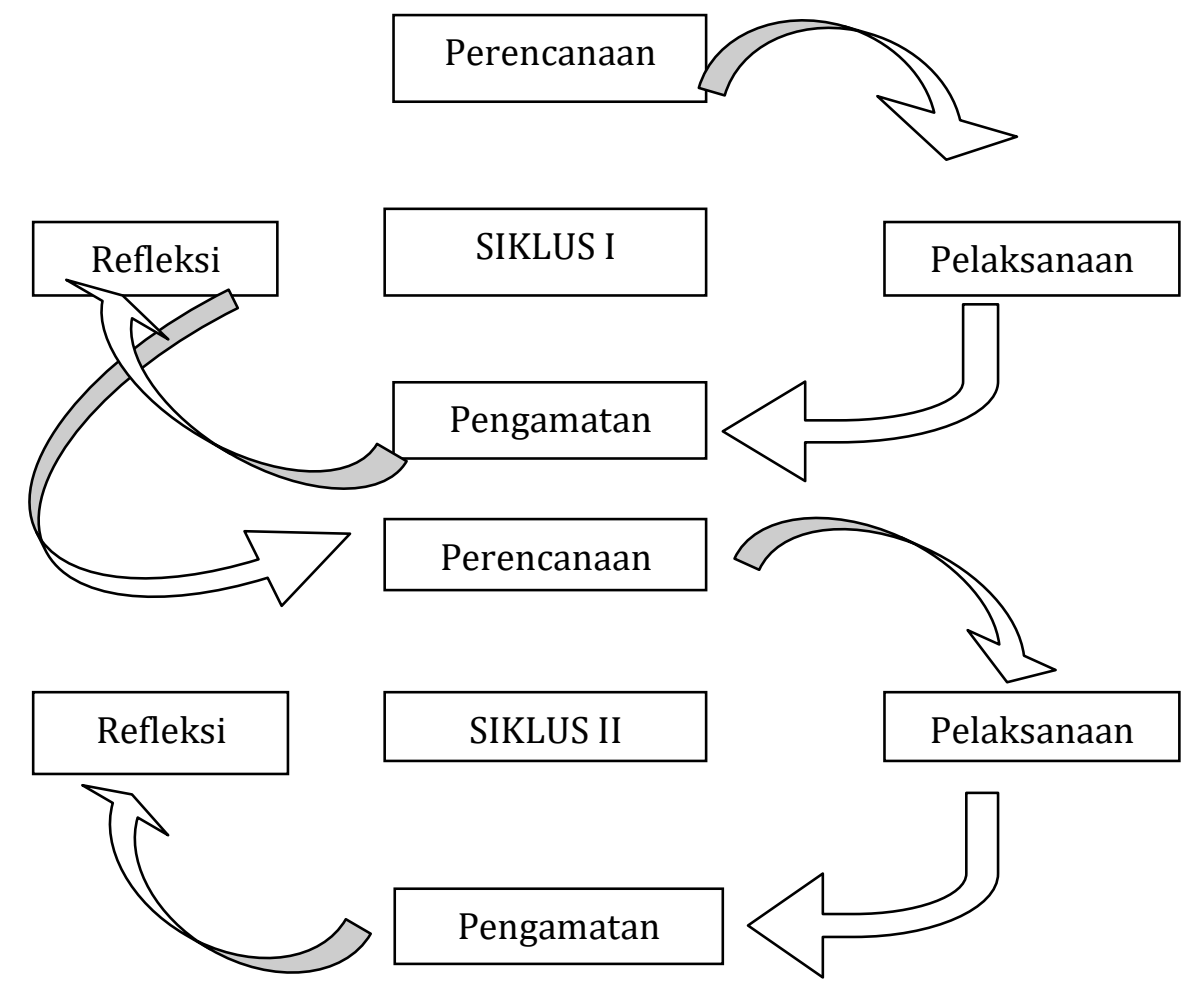

Gambar 1. Penelitian Tindakan Model Kemmis dan Mc Taggart

\section{a. Perencanaan}

Penelitian ini direncanakan terdiri dari 2 siklus, tiap siklus dilaksanakan 2 kali pertemuan sesuai dengan indikator yang ingin diperoleh yakni 80\% atau 12 anak dari seluruhnya yang berjumlah 15 kemampuan mengenal angkanya dapat meningkat. Hasil pengamatan dalam setiap siklus sebagai dasar untuk menentukan tindakan yang tepat dalam rangka mengembangkan kemampuan kognitif pada anak.

Langkah-Langkah Pelaksanaan

\section{1) Perencanaan}

Pada siklus I dilakukan dalam 1 kali pertemuan melalui bermain jari yang didahului oleh perencanaan yang meliputi:

a) Refleksi awal sebagai langkah identifikasi permasalahan yang dihadapi anak dan penetapan subjek penelitian serta menyusun rencana kegiatan harian dalam penelitian ini.

b) Menyusun lembar pengamatan mengenai kehadiran dan keaktifan anak.

c) Menyusun lembar pengamatan mengenai keaktifan guru dalam proses pembelajaran.

\section{2) Pelaksanaan}

a) Mempersiapkan anak dalam proses pembelajaran 
b) Guru membimbing anak dalam mengucapkan salam doa belajar beserta artinya.

c) Guru mempersiapkan bahan pembelajaran

d) Anak diminta untuk mulai berhitung dengan memakai jarinya

e) Guru bersama anak melakukan perhitungan 1-10 secara bersama-sama

f) Guru bersama anak melakukan tanya jawab tentang kegiatan yang telah mereka lakukan.

g) Memberikan himbauan dan motivasi kepada anak untuk lebih giat lagi belajar.

h) Menutup pelajaran.

\section{3) Pengamatan}

Tahap pengamatan dilaksanakan selama penelitian berlangsung. Kegiatan ini berupa mengecek kehadiran anak, partisipasi anak dalam kelompok, kesiapan anak dalam mengikuti kegiatan pembelajaran. Serta pengamatan terhadap peneliti oleh teman sejawat tentang partisipasi selama proses pembelajaran berlangsung. Lembar pengamatan aktivitas dan respons anak serta guru digunakan untuk mengamati pelaksanaan penelitian tindakan kelas.

\section{4) Refleksi}

Kegiatan refleksi antara lain kegiatan analisis dan interpretasi atas informasi/ hasil yang diperoleh dari pelaksanaan tindakan. Peneliti bersama guru mengkaji, melihat dan mempertimbangkan proses maupun hasil belajar anak berdasarkan kriteria keberhasilan yang ditetapkan. Tahap ini dilaksanakan pada proses pembelajaran siklus 1 dan menjadi pertimbangan untuk melanjutkan ke siklus 2 .

\section{Subjek Penelitian}

Subjek penelitian ini adalah anak kelas A di Raudhatul Athfal Ma'arif 01 Metro tahun pelajaran 2018/2019 sebanyak 15 anak.

\section{Metode Pengumpulan Data}

Metode yang digunakan dalam mengumpulkan data yaitu, Metode dokumentasi, wawancara dan pengamatan.

\section{Teknik analisis data}

Teknik analisis data yang digunakan adalah statistik deskriptif kuantitatif. 


\section{Hasil dan Pembahasan}

Penelitian ini dilakukan untuk mengembangkan kemampuan kognitif anak dengan menerapkan metode bermain jari dan dapat dikatakan berhasil jika 80\% dari seluruh jumlah anak kelas A telah mencapai standar penilaian dengan predikat Berkembang Sangat Baik, dan memenuhi 4 indikator yang peneliti tetapkan dari teori indikator perkembangan kognitif pada anak usia dini dan yang telah disepakati antara guru dan peneliti, yaitu:

1. Anak mampu memahami konsep banyak dan sedikit.

2. Anak mampu menyebutkan nama benda satu sampai sepuluh.

3. Anak mampu mengenal konsep bilangan.

4. Anak mampu mengenal lambang bilangan.

Sesuai dengan hasil pengamatan, wawancara dan dokumentasi yang penulis dapatkan selama penelitian tindakan kelas pada siklus I dan II dengan menerapkan metode bermain jari, maka dapat dijelaskan sebagai berikut:

\section{Hasil Tindakan Pada Siklus I}

\section{a. Perencanaan}

Pada tahap ini, guru bekerjasama dengan peneliti untuk menentukan urutan materi pembelajaran dan pembahasannya kemudian membuat rencana kegiatan harian yang terdiri dari ketentuan: Standar kompetensi, Kompetensi Dasar, indikator, materi pembelajaran, media pembelajaran dan penilaian dan melengkapi instrumen peraga seperti gambar angka, gambar jari, kertas A4 dan pensil serta crayon. Guru dan peneliti menentukan pada kegiatan pembelajaran ini memakai metode bermain jari disertai pembuatan lembar pengamatan untuk mengamati aktivitas anak, aktivitas guru dan kegiatan pembelajaran. Kegiatan terakhir peneliti dan guru merancang instrumen penilaian berdasarkan tujuan pembelajaran.

\section{b. Pelaksanaan Tindakan}

Guru dan peneliti bergantian sebagai pengamat dan sebagai pengajar pada pertemuan pertama dan kedua. Penjelasannya antara lain sebagai berikut

1) Kegiatan Awal

a) Guru mengadakan apersepsi mengurutkan angka 1-10. Dengan cara memberikan pertanyaan yang menuju ke materi. Dengan tujuan untuk mengetahui sejauh mana pengertian anak tentang angka, menyebutkan angka 1-10 dengan jari, dan menghubungkan angka dengan gambar jari.

b) Setelah anak melaksanakan tugas pretes, dilanjutkan guru memberikan informasi tentang materi pembelajaran mengenal angka yang akan dipelajari bersama dengan mempergunakan instrumen bantu kartu angka dan jari.

\section{2) Kegiatan Inti}

a) Anak memperhatikan penjelasan dari guru. 
b) Guru menunjukkan bilangan 1 sampai 10. Guru memberi contoh menyebutkan angka 1-10 secara urut.

c) Guru dan anak menyebutkan angka dengan memakai jari.

d) Guru menerangkan dengan memasangkan angka sesuai jumlah jari.

e) Anak secara bergantian mengurutkan angka memakai jari secara bergantian.

f) Guru mengulangi materi yang dirasa anak sulit dimengerti.

\section{3) Kegiatan Penutup}

a) Guru bersama anak membuat simpulan bersama.

b) Guru memberi motivasi kepada anak menggunakan nyanyian atau yel-yel.

\section{c. Pengamatan/Pengamatan}

Hasil pengamatan pada siklus I materi pelajaran kemampuan mengenal angka melalui metode jari, di antaranya aktivitas guru masih perlu ditingkatkan, terutama aktivitas guru dalam menyiapkan rencana kegiatan harian, berinteraksi dan membimbing anak dan membuat kesimpulan. Dari hasil pengamatan perlu adanya perubahan yang lebih baik sehingga perlu adanya tindakan pada siklus berikutnya agar perubahan dapat lebih baik dari siklus sebelumnya.

Setelah dilakukan pengamatan pada siklus I, berikut hasil persentase nilai anak yang telah kemampuan kognitifnya berkembang pada siklus I:

Tabel 8 Persentase Perkembangan Kemampuan Kognitif Anak Kelas A Raudhatul Athfal Ma'arif 01 Metro Pada Pra Survei dan Siklus I

\begin{tabular}{|c|c|c|c|c|}
\hline No & Hasil & Standar Penilaian & $\begin{array}{c}\text { Jumlah } \\
\text { Anak }\end{array}$ & Persentase \\
\hline \multirow{3}{*}{1.} & \multirow{3}{*}{$\begin{array}{l}\text { Pra } \\
\text { Survei }\end{array}$} & Belum Berkembang & 6 & $40 \%$ \\
\hline & & Mulai Berkembang & 3 & $20 \%$ \\
\hline & & Berkembang Sangat Baik & 6 & $40 \%$ \\
\hline \multirow{3}{*}{2.} & \multirow{3}{*}{ Siklus I } & Belum Berkembang & 3 & $20 \%$ \\
\hline & & Mulai Berkembang & 3 & $20 \%$ \\
\hline & & Berkembang Sangat Baik & 9 & $60 \%$ \\
\hline
\end{tabular}

Sesuai dengan persentase di atas, maka perkembangan kognitif anak setelah adanya penerapan metode bermain jari pada siklus I sudah termasuk cukup baik namun belum mencapai indikator keberhasilan 80\%, karena jumlah peserta didik yang nilainya mencapai berkembang sangat baik hanya meningkat menjadi $60 \%$ dari hasil pra survei sebelumnya $40 \%$. 


\section{d. Refleksi}

Sesuai dengan pengamatan/pengamatan dapat diketahui bahwa sebagian anak belum dapat memusatkan perhatiannya dalam proses pembelajaran. Maka pembelajaran pada siklus II perlu ditekankan pada perhatian anak dan keefektifan waktu. Karena kurang tertibnya anak dalam proses pembelajaran kemampuan kognitif maka menyebabkan pembelajaran kurang begitu maksimal sehingga masih ada anak yang belum tepat dalam mengurutkan angka secara benar. Oleh karena itu siklus II dalam pembelajaran perlu ditekankan perhatian anak dan suasana yang tertib dalam pembelajaran.

\section{Hasil Tindakan Pada Siklus II}

\section{a. Perencanaan}

Dalam tahap ini, guru bekerjasama bersama peneliti/observer dalam menentukan urutan materi pembelajaran dan cakupannya kemudian membuat rencana kegiatan harian mencangkup ketentuan: Standar kompetensi, Kompetensi Dasar, indikator, materi pembelajaran, media pembelajaran dan penilaian dan melengkapi instrumen peraga seperti gambar angka, gambar jari, kertas A4 dan pensil serta crayon.

Peneliti meningkatkan kualitas kegiatan pembelajaran dari siklus I. Peneliti mengajak anak bernyanyi dan meneriakkan yel-yel. Materi disampaikan menggunakan kartu angka dan gambar jari untuk menarik perhatian anak.

\section{b. Pelaksanaan Tindakan}

Pada siklus II guru dan peneliti bergantian menjadi pengajar dan pengamat. Pada pertemuan pertama peneliti sebagai pengamat dan pada pertemuan kedua peneliti sebagai pengajar. Urutan kegiatannya sebagai berikut

\section{1) Kegiatan Awal}

a) Guru mengadakan apersepsi dengan cara mengulang pembelajaran pada siklus I menyebutkan angka 1-10 secara urut. Tujuannya untuk mengecek sejauh mana pemahaman anak tentang angka, menyebutkan angka dengan jari.

b) Setelah itu guru menyampaikan informasi tentang pembelajaran mengenal angka yang akan disampaikan menggunakan media kartu angka dan gambar jari.

\section{2) Kegiatan Inti}

a) Anak menyimak penjelasan guru.

b) Guru menunjukkan urutan angka 1 sampai 10 . Kemudian guru memberi contoh menyebutkan urut angka 1 sampai 10.

c) Guru menunjukkan gambar jari kemudian menyebutkannya bersama anak-anak. Kemudian anak menyebutkan angka 1-10 secara urut dan menyamakan dengan gambar jari secara bergantian. 
d) Anak mencari gambar jari untuk dipasangkan dengan angka dengan tepat.

e) Guru mengulangi materi yang telah diajarkan.

\section{3) Kegiatan Penutup}

a) Guru menyimpulkan materi pelajaran yang disampaikan.

b) Guru mengakhiri kegiatan dengan memberikan motivasi kepada anak.

\section{c. Pengamatan/Pengamatan}

Hasil pengamatan antara lain, anak ceria, aktif dan antusias mengikuti proses pembelajaran. Peran guru dalam meningkatkan aktivitas siswa semakin meningkat. Guru mulai mengarahkan anak lebih aktif dan tertib dalam mengikuti proses pembelajaran.

Setelah melalui siklus II, berikut hasil persentase nilai anak yang kemampuan kognitifnya berkembang pada siklus II:

Tabel 9 Persentase Perkembangan Kemampuan Kognitif Anak Kelas A Raudhatul Athfal Ma'arif 01Metro Pada Pra Survei, Siklus I dan Siklus II

\begin{tabular}{|c|c|c|c|c|}
\hline \multirow{2}{*}{ No } & \multirow{2}{*}{ Hasil } & Standar Penilaian & $\begin{array}{c}\text { Jumlah } \\
\text { Anak }\end{array}$ & Persentase \\
\hline \multirow{3}{*}{1.} & \multirow{2}{*}{ Pra Survei } & Belum Berkembang & 6 & $40 \%$ \\
\cline { 3 - 5 } & & Mulai Berkembang & 3 & $20 \%$ \\
\cline { 3 - 5 } 2. & \multirow{3}{*}{2.} & Berkembang Sangat Baik & 6 & $40 \%$ \\
\cline { 3 - 5 } & & Belum Berkembang & 3 & $20 \%$ \\
\hline \multirow{3}{*}{3} & \multirow{2}{*}{ Siklus II } & Mulai Berkembang & 3 & $20 \%$ \\
\cline { 3 - 5 } & & Berkembang Sangat Baik & 9 & $0 \%$ \\
\cline { 3 - 5 } & & Belum Berkembang & 0 & $20 \%$ \\
\cline { 3 - 5 } & & Mulai Berkembang & 3 & $80 \%$ \\
\hline
\end{tabular}

Sesuai dengan persentase di atas, maka perkembangan kognitif anak melalui adanya tindakan penerapan metode bermain jari dalam mengenalkan angka dan lambang bilangan pada anak kelas A sudah bisa dikatakan baik dan maksimal, karena jumlah anak yang Berkembang Sangat Baik berkembang menjadi 12 anak yang tadinya hanya 9 anak pada siklus I. Dari siklus I dan Siklus II ini ternyata standar pencapaian yang ditargetkan yaitu $80 \%$ sudah tercapai.

\section{d. Refleksi}

Sesuai dengan pengamatan di atas, dapat diketahui bahwa anak telah memanfaatkan waktu dengan lebih baik. Semangat anak meningkat dalam melakukan kegiatan belajar sambil bermain memakai media kartu angka dan gambar jari. Guru memberikan motivasi kepada anak agar lebih aktif lagi dalam kegiatan belajar pada pertemuan-pertemuan yang lainnya. Dengan tercapai 
indikator keberhasilan sebesar 80\% dari keseluruhan anak yang ada, maka penelitian tindakan kelas ini peneliti cukupkan sampai di sini.

Sesuai dengan penjabaran di atas, maka standar penilaian yang ada yakni Belum Berkembang, Mulai Berkembang dan Berkembang Sangat Baik yang didapatkan anak selama pembelajaran berlangsung pada pra survei atau pengamatan awal, siklus I dan siklus II melalui penerapan metode bermain jari dapat dijelaskan dalam grafik sebagai berikut.

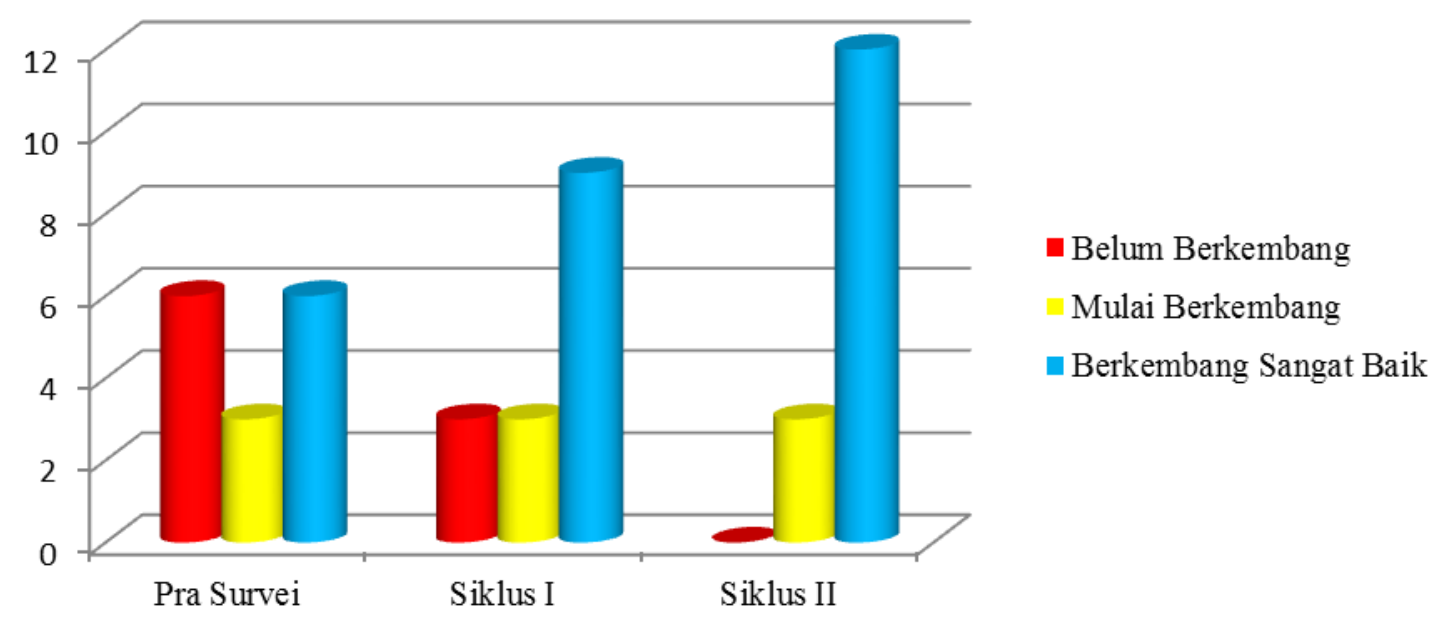

\section{Grafik 1 Perkembangan Kemampuan Kognitif Anak Kelas A Raudhatul Athfal Ma'arif 01 Metro Pada Pra Survei, Siklus I dan Siklus II}

\section{Simpulan}

Sesuai hasil tersebut, penulis menyimpulkan bahwa setelah diterapkan metode bermain jari sebagai metode pembelajaran dalam mengembangkan kemampuan kognitif dalam mengenal angka dan lambang bilangan pada anak kelas A Raudhatul Athfal Ma'arif 01 Metro yang dilakukan melalui penelitian tindakan kelas pada siklus I dan II dapat diperoleh hasil perkembangan anak pada tiap siklusnya dan menunjukkan hasil yang sangat baik.

\section{E. Daftar Rujukan}

Arikunto, suharsimi. (2009). Praktik Penelitian Tindakan Kelas (II). Bandung: Rosdakarya.

Fakhruddin, A. . (2010). Sukses Menjadi Guru TK-PAUD. Jogjakarta: Bening. Harjanto, B. (2011). Agar Anak Anda Tidak Takut Pada Matematika. Jakarta: Manika Books.

Kemendiknas. (2009). Peraturan Menteri Pendidikan Nasionala Republik Indonesia Nomor 58 Tahun 2009. Jakarta: Depdiknas. 
Musbikin, I. (2010). Buku Pintar PAUD. Jogjakarta: Laksana.

Rahayu, N. (2010). Fingermath Jari Ajaib. Jakarta: Hi Kids.

Setiawan, A. (2018). Meningkatkan kemampuan berhitung anak usia dini melalui media pembelajaran matematika di ra ma'arif 1 kota metro. Seling:Jurnal Program Studi PGRA, 4, 181-188.

Setyaki, A. (2008). Aritmatika Jari Matode AHA. Jakarta: Khalifa.

Wahyudi, C. (2005). Program Pendidikan Untuk AUD Di Prasekolah Islam. Jakarta: PT. Grasindo. 